\title{
Comparison of conventional and molecular techniques for Trypanosoma vivax diagnosis in experimentally infected cattle
}

Comparação de técnicas convencionais e moleculares para diagnóstico em bovinos experimentalmente infectados por Trypanosoma vivax

Otavio Luiz Fidelis Junior ${ }^{1,2 *}$ (1); Paulo Henrique Sampaio ${ }^{2}$; Luiz Ricardo Gonçalves²; Marcos Rogério André2; Rosangela Zacarias Machado²; Gene Wijffels ${ }^{3}$; Fabiano Antonio Cadioli ${ }^{2,4}$

${ }^{1}$ Universidade Vila Velha - UVV, Vila Velha, ES, Brasil

${ }^{2}$ Faculdade de Ciências Agrárias e Veterinárias - FCAV, Universidade Estadual Paulista Júlio de Mesquita Filho - UNESP, Jaboticabal, SP, Brasil

${ }^{3}$ Commonwealth Scientific and Industrial Research Organisation - CSIRO, Brisbane, Queensland, Australia

${ }^{4}$ Faculdade de Medicina Veterinária, Universidade Estadual Paulista Júlio de Mesquita Filho - UNESP, Araçatuba, SP, Brasil

Received October 24, 2018

Accepted April 22, 2019

\begin{abstract}
Livestock infections by Trypanosoma vivax have been occurring with increasing frequency, mainly due to the presence of animals with subclinical infections and without apparent parasitaemia, making diagnosis challenging. The aim of the present study was to evaluate several techniques used for T. vivax diagnosis in order to assess the best way of using them during the course of the disease. Molecular methods demonstrated higher rates of detection than parasitological methods, detecting 33 of the 54 (61.1\%) known positive samples, while the hematocrit centrifugation technique (best parasitological test) detected only $44.4 \%$. The serological methods, IFAT and ELISA, detected seropositivity in 51 of the 54 (94.4\%) and 49 of the 54 (90.7\%) known positive samples, respectively. Despite being highly sensitive, the latter only demonstrates exposure to the infectious agent and does not indicate whether the infection is active. The present study was the first to use the qPCR for a South American isolate, improving disease detection and quantification. Furthermore, the analyses revealed that the patent phase of the disease may extend up to 42 days, longer than previously reported. The combination of several diagnostic techniques can lower the frequency of false negative results and contributes toward better disease control.
\end{abstract}

Keywords: PCR, qPCR, serology, trypanosomosis, diagnosis.

\section{Resumo}

Infecçôes por Trypanosoma vivax têm ocorrido com frequência crescente em animais de produção, principalmente pela aquisição de animais com infecçôes subclínicas e sem aparente parasitemia, o que dificulta o diagnóstico. O objetivo do presente estudo foi avaliar várias técnicas empregadas para o diagnóstico de T. vivax, a fim de verificar a melhor maneira de utilizá-las durante o curso da doença. Os métodos moleculares demonstraram maiores taxas de detecçáo que os métodos parasitológicos, detectando 33 das 54 (61,1\%) amostras sabidamente positivas, enquanto a técnica de hemoconcentração (melhor teste parasitológico) detectou apenas 44,4\%. Os métodos sorológicos, RIFI e ELISA, detectaram soropositividade em 51 das $54(94,4 \%)$ e 49 das $54(90,7 \%)$ amostras sabidamente positivas, respectivamente. Apesar de serem altamente sensíveis, estes testes apenas demonstram a exposição ao agente infeccioso, e não indicam se a infecção permanece ativa. O presente estudo foi o primeiro a utilizar a qPCR para um isolado sul-americano, melhorando sua detecção e quantificação. Além disso, as análises revelaram que a fase patente da doença pode se estender por até 42 dias após a infecção, sendo maior que anteriormente relatado. A combinação de várias técnicas de diagnóstico pode evitar a frequência de resultados falso-negativos e contribuir para um melhor controle da doença.

Palavras-chave: PCR, qPCR, sorologia, tripanossomose, diagnóstico. 


\section{Introduction}

Trypanosomosis is a widely distributed parasite-associated disease that affects humans and animals. Trypanosoma vivax cause significant economic losses in livestock, being responsible for major losses in sub-Saharan Africa and Central and South America (DÁVILA \& SILVA, 2000). Infections by T. vivax in livestock have been occurring with increasing frequency in tropical and subtropical regions (DÁVILA \& SILVA, 2000; GIORDANI et al., 2016). In cattle, T. vivax diagnosis is difficult, since the parasite triggers non-specific symptoms such as fever, anorexia, weight loss, reduced milk production, abortions, and neurological signs (BATISTA et al., 2007; CADIOLI et al., 2012). Moreover, there are fluctuations in parasitaemia and apparently aparasitemic intervals (DESQUESNES, 2004; CADIOLI et al., 2015; FIDELIS et al., 2016).

Direct parasitological methods present poor sensitivity during low parasitaemia or aparasitemic periods, which are common in chronic infection (DESQUESNES, 2004; CADIOLI et al., 2015). Serological tests, including indirect immunofluorescent antibody test (IFAT), enzyme-linked immunosorbent assay (ELISA), and immuno-chromatographic rapid diagnostic test (RDT), are the tools of choice for herd screening but do not indicate if the infection is active or if the animal has responded to treatment (CADIOLI et al., 2012, 2015; BOULANGÉ et al., 2017). On the other hand, molecular methods such as conventional polymerase chain reaction (PCR) and real-time PCR (qPCR) have the potential to be excellent diagnostic tools; however, these techniques are subject to false negative results when the parasitaemia is below the detection level (CADIOLI et al., 2015; KATO et al., 2016).

For trypanosomiasis control, integrated approaches such as vector control, improved general health and immunocompetence of affected herds, and the use of more sensitive and rapid diagnostic tools are necessary (GIORDANI et al., 2016). Thus, the present study aimed to evaluate the use of several techniques for T. vivax diagnosis during the course of the disease in order to assess the best way of use them.

\section{Materials and Methods}

\section{Experimental infection and sample collection}

The present experiment was approved by the Animal Ethics Committee of the São Paulo State University (Unesp) School of Agricultural and Veterinarian Sciences under the process number 13219/15. Three Girolando cows aged six to seven years were experimentally infected via the intravenous route with $2.0 \times 10^{7}$ trypomastigotes of T. vivax, "Lins" isolate (CADIOLI et al., 2012; GARCIA et al., 2014), being this a complementary work to the study developed by Fidelis et al. (2016). Blood sampling of each animal occurred seven day before inoculation (-7 DAI), on the day of inoculation (0 DAI), the day after inoculation (1 DAI) and then weekly till 119 days after infection (DAI). At each bleed, $3 \mathrm{~mL}$ of whole blood was obtained by jugular venipuncture and collected into a vacutainer tube containing 10\% K2-EDTA, and $10 \mathrm{~mL}$ was collected into an anticoagulant-free vacutainer tube
(B.D. - Juiz de Fora - MG). Blood and serum samples were split into triplicates and stored at $-80{ }^{\circ} \mathrm{C}$ until required for analyses. Samples from the 1 DAI until 119 DAI were considered as positives.

\section{Parasitological methods}

The EDTA-treated blood was used to assess the presence of the parasite and quantify the level of parasitaemia on the day of sampling. Parasites were detected by the hematocrit centrifugation technique as described by Woo (1970), and blood smears were stained with the May-Grunwald-Giemsa. For parasite quantification, the thick-drop counting method described by Brener (1961) was performed using $5 \mu \mathrm{L}$ of whole blood placed on a microscope slide under a $22 \mathrm{~mm}^{2}$ coverslip. Trypomastigote forms were counted in 50 microscopic fields under a $40 \mathrm{X}$ objective. The parasite count was multiplied by the microscope correction factor, and the result expressed in parasites per mL blood (BRENER, 1961).

\section{Serological methods}

In order to obtain antigen for use in the IFAT and ELISA methods, trypomastigotes were purified from the whole blood of a goat experimentally infected with T. vivax, "Lins" isolate (CADIOLI et al., 2012; GARCIA et al., 2014). Purification was performed as described by González et al. (2005).

IFAT was conducted as described by Aquino et al. (1999) with minor modifications. Teflon printed diagnostic slides (Perfecta ${ }^{\circledR}$, Sáo Paulo, Brazil) previously coated with purified T. vivax trypomastigotes were thawed at room temperature for $10 \mathrm{~min}$ and to each well, successive dilutions of each test serum sample were added, starting at 1:80 and ending at 1:1280. Samples that were reactive at the 1:80 dilution were considered seropositive.

The ELISA was carried out as described by Aquino et al. (1999), with minor modifications as described below. Each microplate well (Nunc MaxiSorp $^{\circledR}$ ) was coated with $100 \mu \mathrm{L}$ of the soluble antigen at a concentration of $400 \mathrm{ng} / \mathrm{mL}$. Sera were tested in duplicate, and positive and negative controls were tested in quadruplicate. All samples and controls were diluted 1:50 in phosphate-buffered saline with Tween-20 ([PBST]; $130 \mathrm{mM} \mathrm{NaCl}, 2.7 \mathrm{mM} \mathrm{KCl}$, $5.6 \mathrm{mM} \mathrm{Na}_{2} \mathrm{HPO}_{4}, 1 \mathrm{mM} \mathrm{KH} \mathrm{PO}_{4}, 0.92 \mathrm{mM} \mathrm{NaH}_{2} \mathrm{PO}_{4}$ and $0.05 \%$ Tween 20$)$. The reaction was read by a microplate reader (MRX TC Plus, Dynex Technology, USA) at $405 \mathrm{~nm}$. The blank well did not contain serum. The mean absorbance and standard deviation for the positive and negative control serum samples were $1.121 \pm 0.081$ and $0.234 \pm 0.034$, respectively. The cut-off point was calculated as 0.335 as described by Madruga et al. (2006).

\section{Molecular methods}

The DNA extraction was performed with the DNeasy Blood \& Tissue Kit $^{\circledR}$ (Qiagen, Germantown, MD, USA) according to the manufacturer's recommendations, using an aliquot of $200 \mu \mathrm{L}$ of blood. The extracted DNA was stored at $-20^{\circ} \mathrm{C}$ until required.

PCR was performed using a set of primers based on the DNA sequence of the T. vivax CatL gene as described by Cortez et al. (2009), in a final volume of $50 \mu \mathrm{L}$ containing 
a specific PCR mixture: (1) 20-100 ng of genomic DNA (except the negative control); (2) 100 pmol of DTO 155 (5'-TTAAAGCTTCCACGAGTTCTTGATGATCCAGTA-3') and TviCatL1 (5'- GCCATCGCCAAGTACCTCGCCGA-3') primers; (3) $200 \mu \mathrm{M}$ of each dNTP; (4) $20 \mathrm{mM}$ of Tris- $\mathrm{HCl}$ (pH 8.4); (5) $50 \mathrm{mM} \mathrm{KCl}$; (6) $1.5 \mathrm{mM}$ of $\mathrm{MgCl}_{2}$; (7) 7.5\% (v/v) dimethyl sulfoxide; (8) $0.1 \mathrm{mg} / \mathrm{mL}$ of bovine serum albumin; and (9) $2.5 \mathrm{U}$ of Taq DNA polymerase (Invitrogen, Carlsbad, CA, USA). Reactions were conducted in a thermocycler $\mathrm{T} 100^{\mathrm{TM}}$ Thermal Cycler (Bio-Rad, Hercules, CA, USA) under specific conditions: (1) initial denaturation at $94^{\circ} \mathrm{C}$ for $3 \mathrm{~min}$ followed by 35 cycles of denaturation at $94^{\circ} \mathrm{C}$ for $1 \mathrm{~min}$; (2) annealing at $65^{\circ} \mathrm{C}$ for $1 \mathrm{~min}$ and extension at $72^{\circ} \mathrm{C}$ for $1 \mathrm{~min}$; and (3) a final extension at $72{ }^{\circ} \mathrm{C}$ for $10 \mathrm{~min}$. A positive control template, genomic DNA from T. vivax, isolate "Lins" (GARCIA et al., 2014), was included also. The PCR products were separated on $2 \%$ agarose gel containing ethidium bromide. The gel image was obtained using the ChemiDoc ${ }^{\mathrm{TM}} \mathrm{MP}$ imaging system (Bio-Rad). DNA size standards (GeneRuler 50 bp DNA Ladder; Thermo Fisher Scientific; Waltham, MA, USA) were incorporated in the gel. Relative quantification of the band intensities was performed using the Image Lab ${ }^{\mathrm{TM}}$ Software 5.2.1 (Bio-Rad). The intensities of the PCR products were compared to the intensity of positive control product of each gel run.

TaqMan qPCR was performed as described by Silbermayr et al. (2013). Primers for concurrent detection of the ITS1 regions of $T$. congolense, $T$. brucei and T. vivax and for the bovine toll-like-receptor 8 (TLR-8) (endogenous gene) were initially used with the addition of probes labelled with FAM fluorophore and BHQ2 quencher for T. vivax detection and HEX fluorophore and BHQ2 quencher for TLR-8 detection. Reactions were performed using $5 \mu \mathrm{L}$ of genomic DNA (except for the negative control), 200 nM of Tryps_KS-for (5'-CGTGTCGCGATGGATGACTT-3'), Tryps_KS-rev (5'- CAAACGGCGCATGGGAG-3'), TLR8-for (5'- TGTTTAGAGGAAAGGGATTGGG-3') and TLR8-rev (5'-TTGGTTGATGCTCTGCATGAG-3') primers, $160 \mathrm{nM}$ of T. vivax (FAM-ATGACCTGCAGAACCACTCGATTACCCAGT-BHQ2) probe, 120nM of TLR-8(HEX-CCCGGGTCTAGCCATCATCGACAABHQ2) probe, buffer $2 \mathrm{X}\left(6 \mathrm{nM}\right.$ of $\mathrm{MgCl}_{2}, 0.8 \mathrm{mM}$ of dNTPs and $1 \mathrm{U}$ of Taq DNA polymerase, GoTaq Hot Start Polymerase (Promega, Madison, USA)). The final volume was $25 \mu \mathrm{L}$. qPCR amplifications were conducted in low-profile 96-well unskirted PCR plates (Bio-Rad) using a CFX96 thermal cycler (Bio-Rad) under specific conditions: (1) initial denaturation at $95{ }^{\circ} \mathrm{C}$ for $10 \mathrm{~min}$; (2) 45 cycles at $95^{\circ} \mathrm{C}$ for $30 \mathrm{~s}$ and $61^{\circ} \mathrm{C}$ for $1 \mathrm{~min}$; and (3) termination at $72{ }^{\circ} \mathrm{C}$ for $1 \mathrm{~min}$. All samples were processed in duplicate.

The sensitivity of the qPCR assay was tested with gBlock ${ }^{\circledR}$ Gene fragments (Integrated DNA Technologies ${ }^{\circledR}$, Coralville, IO, USA) containing the target sequences for amplification of T. vivax ITS1 region. Serial dilutions were made in order to construct patterns with different concentrations of gBlock $^{\circledR}$ containing the target sequence $\left(2.0 \times 10^{7}\right.$ to 2.0 copies/ $\left.\mu \mathrm{L}\right)$. The copy number was determined according to the formula $\left(\mathrm{Xg} / \mu \mathrm{L}\right.$ DNA/ $\left[\mathrm{gBlock}^{\circledR}\right.$ size $\left.\left.(\mathrm{bp}) \times 660\right]\right)$ $\times 6.022 \times 10^{23} \times$ copies of $\left.\mathrm{gBlock}^{\circledR} / \mu \mathrm{L}\right)$. The amplification efficiency (E) was calculated according to the slope of the standard curve of each run according to the following formula $\left(\mathrm{E}=10^{-1 / \text { slope }}\right)$.

\section{Statistical analysis}

The Kappa concordance test was performed between the different techniques used. In addition, two Spearman's correlation tests were performed. The first was between the values obtained from the parasitaemia estimated by the thick-drop count and those determined by qPCR, and the second correlation was determined for the relationship between the qPCR values and those obtained by the relative intensity of the PCR products.

\section{Results}

The results are presented in Table 1 and Figure 1 and show the presence of trypomastigotes from the second post-infection collection (7 DAI) as verified by the three parasitological methods. Among the methods used for direct parasite detection, the hematocrit centrifugation technique had the highest detection capability, detecting 24 of 54 known positive samples (44.4\%). However, the thick-drop and stained blood smear techniques showed similar detection capabilities, detecting 17 of 54 known positive samples $(31.5 \%)$ (Table 1$)$.

The IFAT and ELISA techniques performed comparably with the IFAT being slightly more sensitive, detecting seropositivity in 51 of the 54 known positive samples (94.4\%). From 7 DAI, all animals showed reactivity at the $1 / 80$ serum dilution and after 21 DAI achieved seropositivity at the 1/1280 dilution, maintaining this level (or higher) until the end of the experimental period. The exception was the E1 animal, whose titre dropped to 160 at 119 DAI. The ELISA test detected seropositivity in 49 of the 54 known positive samples (90.7\%). At 7 DAI only one animal (E1) was seropositive, but from $14 \mathrm{DAI}$, all samples were seropositive and remained so throughout the experiment (Table 1).

Regarding the molecular evaluation, all samples were positive for the host endogenous gene $T L R-8$, indicating that extractions were efficient, and showing that the results obtained by both PCR and $\mathrm{qPCR}$ are reliable. The mean and intervals for efficiency, $\mathrm{R}^{2}$, slope, and $\mathrm{y}$-intercept of $\mathrm{qPCR}$ reactions were $93.6 \%$, (90.1-97.1), 0.988 (0.970-0.999), -3.487 (-3.586-(-)3.392) and 39.758 (38.583-41.764), respectively. All duplicates presented a maximum variation of $0.5 \mathrm{Cq}$. Both techniques detected the T. vivax DNA in 33 of the 54 known positive samples $(61.1 \%)$ with the first detection on the first day after infection (1 DAI) (Table 1 and Figure 1).

The highest values of parasitaemia, detected by the thick-drop technique, occurred on $14 \mathrm{DAI}$ with $6.82 \times 10^{6}, 1.62 \times 10^{7}$ and $3.99 \times 10^{6}$ parasites $/ \mathrm{mL}$ of blood for E1, E2 and E3 cows, respectively. The quantification by $\mathrm{qPCR}$ also revealed that the highest parasite values occurred on $14 \mathrm{DAI}$, showing $5.03 \times 10^{7}$, $2.70 \times 10^{8}$ and $8.53 \times 10^{7}$ copies of the target region $/ \mathrm{mL}$ of blood, for E1, E2 and E3 animals, respectively (Table 1 and Figure 1). Fluctuations in parasitaemia were observed during the experimental period both by qPCR and thick-drop techniques, highlighting a patent phase, in which circulating parasites were seen throughout the entire period, and subpatent phase, in which a low parasitaemia was detected followed by aparasitemic periods. The parasitemic curves quantified by the qPCR technique are shown in Figure 1, 


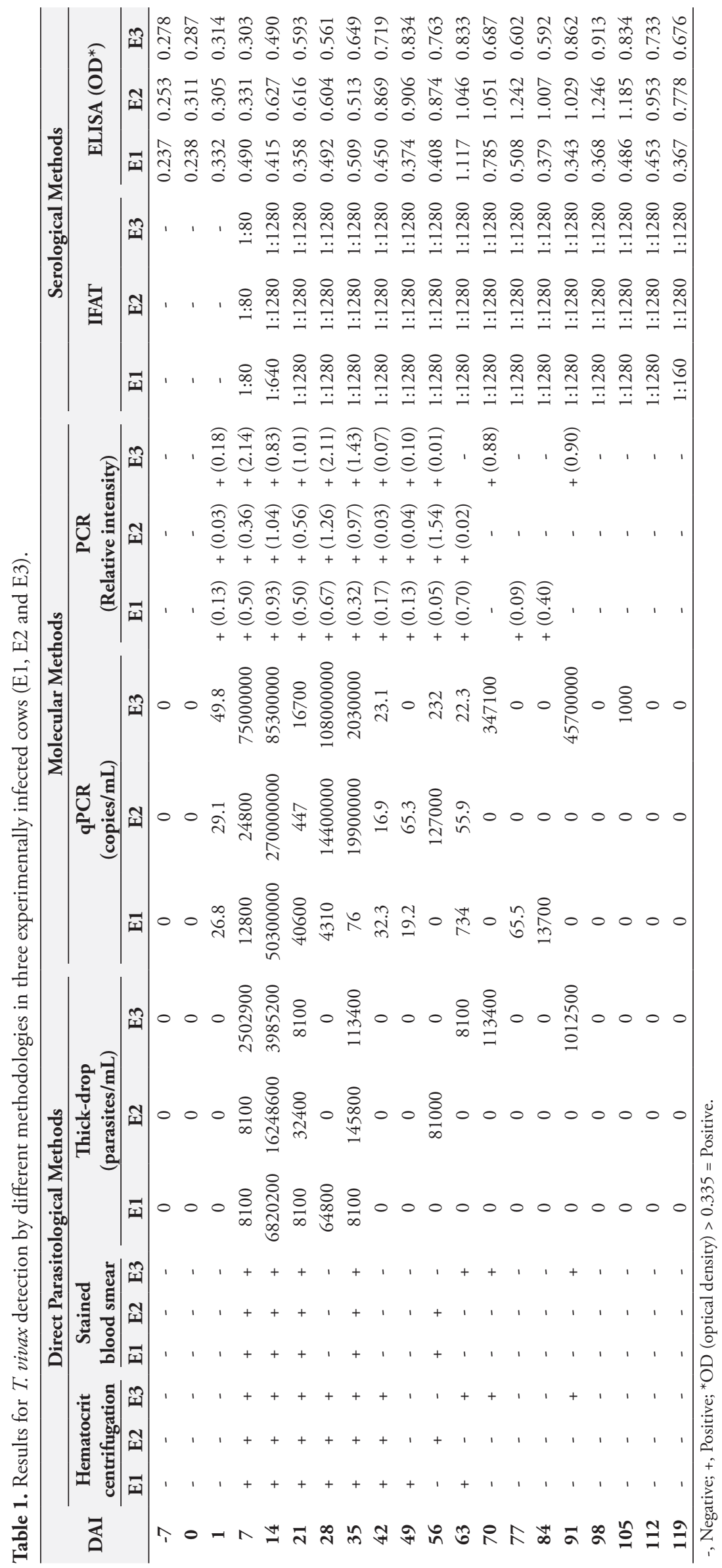




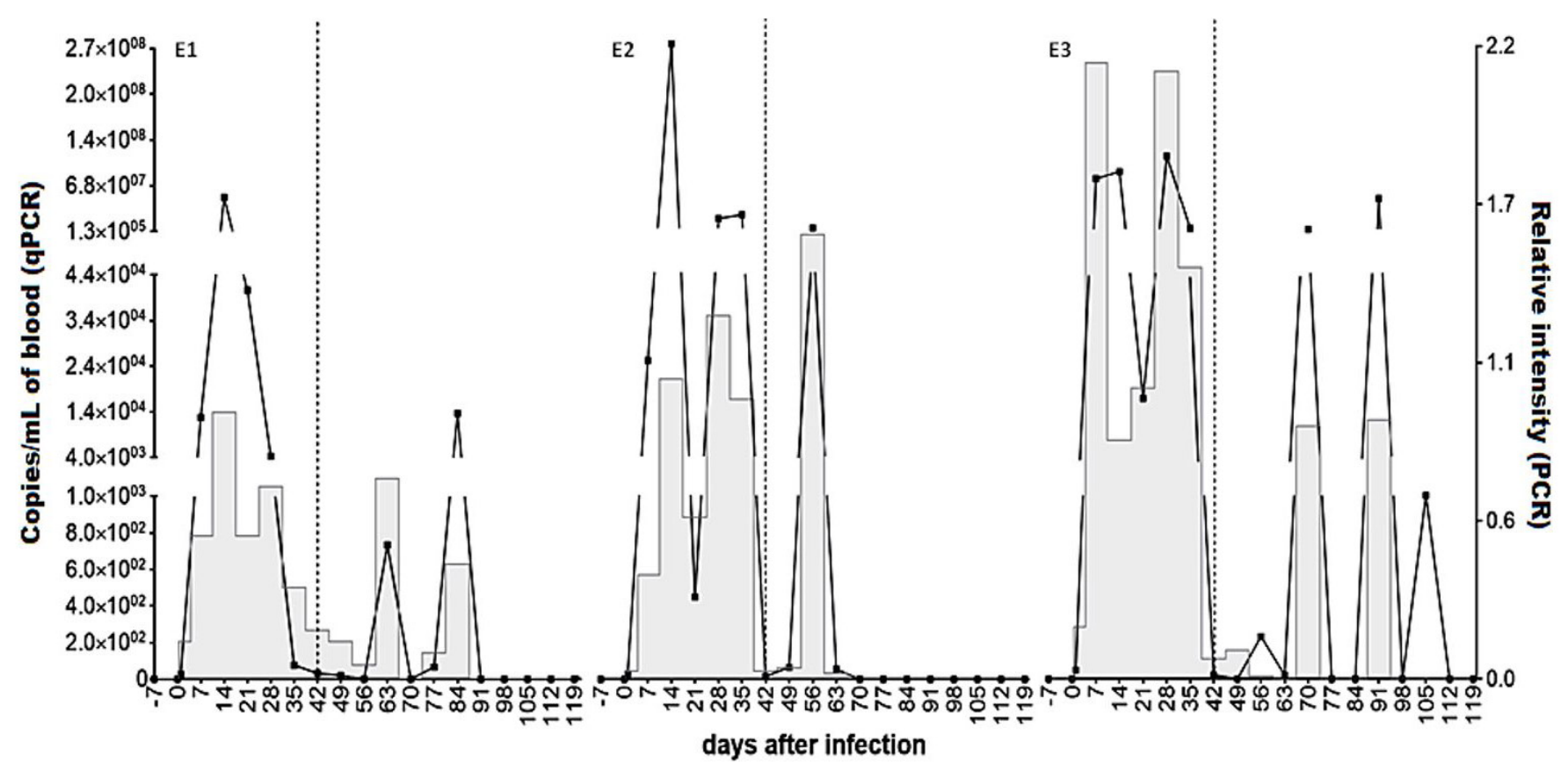

$\longrightarrow$ qPCR;

PCR

Figure 1. Parasitemic curves quantified by qPCR and relative intensity of PCR of three individual cows (E1, E2 and E3) experimentally infected with T. vivax.

Table 2. Results for Kappa concordance test between the several techniques employed for T. vivax diagnosis.

\begin{tabular}{ccccccc}
\hline & $\begin{array}{c}\text { Hematocrit } \\
\text { centrifugation }\end{array}$ & Blood smear & Thick-drop & IFAT & ELISA & PCR \\
\hline $\begin{array}{c}\text { hematocrit centrifugation } \\
\text { blood smear }\end{array}$ & 0.67 & & & & & \\
thick-drop & 0.74 & 0.92 & & & & \\
IFAT & 0.21 & 0.13 & 0.13 & & & \\
ELISA & 0.14 & 0.06 & 0.06 & 0.88 & & \\
PCR & 0.64 & 0.42 & 0.42 & 0.14 & 0.07 & 0.87 \\
qPCR & 0.71 & 0.42 & 0.49 & 0.14 & 0.07 & \\
\hline
\end{tabular}

while the parasitemic curves quantified by thick-drop technique were reported in Fidelis et al. (2016).

Kappa agreement results are presented in Table 2. Both correlation analyses were shown to be positive according to Spearman $r=0.8757$ $(\mathrm{P}<0.0001)$ for the two quantitative techniques, thick-drop technique and qPCR, and Spearman $r=0.9151(\mathrm{P}<0.0001)$ for the $\mathrm{qPCR}$ quantification and PCR relative intensity.

\section{Discussion}

South American isolates of T. vivax do present some genetic differences despite being phylogenetically related to African isolates (GARCIA et al., 2014). The present study was the first to use the qPCR protocol, developed for African isolates (SILBERMAYR et al., 2013), for one South American isolate, detecting the T. vivax DNA, "Lins" isolate. Clearly it will be possible to develop a rapid and accurate measurement of parasite numbers in whole blood through target DNA quantification.
The short pre-patent period verified in the present study, in which molecular methods were used, may have occurred by the highly inoculum concentration employed. This highly concentration was similar to those ones employed in the studies performed by Igbokwe et al. (1996) and Schenk et al. (2001). It was also observed that the PCR assay possessed an identical capacity of detection for $T$. vivax DNA as the qPCR assay (61.1\%). This similarity in detection capacity could be explained by the fact that the qPCR assay described by Silbermayr et al. (2013) was directed to ITS1 region that has a high CG content, which can interfere with the diagnostic accuracy of qPCR (FIKRU et al., 2016). Fluctuations in parasitaemia and aparasitemic intervals make the diagnosis of animal trypanosomiasis challenging since it is difficult to directly detect the parasite, especially in the subpatent phase of infection (CADIOLI et al., 2015); thus, the use of more sensitive diagnostic tools such as PCR and qPCR is necessary. The detection rate of the molecular methods was higher than the parasitological methods. Both molecular techniques were able to identify $61.1 \%$ of the known positive samples, whereas 
the hematocrit centrifugation technique, the best parasitological method, detected $44.4 \%$. The molecular detection rates are similar to that described by Cadioli et al. (2015), who also used the $T$. vivax Cat $L$ target region and worked with experimentally infected cattle. Previously Tran et al. (2014) using the ITS1 as target region when working with experimentally infected cattle, obtained a detection rate of $84.9 \%$.

Through qPCR analysis it was possible to verify that the patent phase of the illness, where parasites can be detected without interruption, may extend up to $42 \mathrm{DAI}$. This is well beyond the $14 \mathrm{DAI}$ and 30 DAI previously reported by Rodrigues et al. (2013) and Fidelis et al. (2016), respectively, which used direct parasitological techniques to quantify the parasitaemia. Thus, the use of more sensitive molecular tool may help in a better understanding of the parasite dynamics during the infection. The two molecular techniques presented similar detection rates, obtaining a Kappa index of 0.87 , which presented a strong agreement (LANDIS \& $\mathrm{KOCH}, 1977)$. Although molecular techniques are effective in detecting infected animals in the patent phase of the disease, they have failed, on some occasions, to detect known positive samples during the subpatent phase. Serological tests can be useful tools for this phase of the illness, especially for cases that occurred in areas considered disease free.

High antibody levels have been described as an efficient mechanism to control parasitaemia (MATTIOLI \& WILSON, 1996), which may explain the findings of the present study where all animals were seropositive from 14 DAI, for both serological techniques. The higher sensitivity of serological tests when compared to parasitological (MATTIOLI et al., 2001) and molecular tests (CADIOLI et al., 2015) suggests their use in epidemiological studies, in which the overall exposure to trypanosome infection is being investigated, and/or in cases in which no treatment was performed or non-specific anti-Trypanosome drugs were used. Care should be taken when using a single ELISA for T. vivax diagnosis, as antibodies are likely to cross-react with other parasites of the same genus (DESQUESNES, 2004). Another complicating factor is that serological tests do not indicate if the infection is active or if the animal has responded to treatment (CADIOLI et al., 2012, 2015; BOULANGÉ et al. 2017). According to Batista et al. (2007), anti-T. vivax antibodies in cattle that did not present clinical signs suggest the occurrence of subclinical disease, a form of the disease in which the detection of circulating parasites is difficult.

Although T. vivax visualization in blood smears is still the main method for the diagnosis of the disease and direct parasitological techniques are widely practiced (DESQUESNES, 2004), these methods presented the lowest sensitivity among the tests evaluated. Serological techniques are efficient in detecting seropositive animals, especially in the subpatent phase of infection, but in spite of being highly sensitive, they only demonstrate exposure to the infectious agent (DESQUESNES, 2004; OSÓRIO et al., 2008). The molecular techniques are highly sensitive, especially in the patent phase of the disease, but also demonstrated good sensitivity during the subpatent phase. They could be used in conjunction with serological techniques in the search of animals that remain infected after treatment (unpublished data). With the emergence of more sensitive and accurate molecular tools we anticipate that in the future the detection of positive animals will be improved, even in cases of low parasitaemias. However, for the present time, the combination of several diagnostic techniques can avoid the generation of false negative results, enable a better disease control and, consequently, the reduction of economic damage generated by $T$. vivax infection of productive cattle.

\section{Acknowledgements}

We thank São Paulo Research Foundation (FAPESP) for financial support in the form of grant given through procedural number 2014/10572-5 and research aid number 2012/02284-3.

\section{References}

Aquino LPCT, Machado RZ, Alessi AC, Marques LC, Castro MB, Malheiros EB. Clinical, parasitological and immunological aspects of experimental infection with Trypanosoma evansi in dogs. Mem Inst Oswaldo Cruz 1999; 94(2): 255-260. http://dx.doi.org/10.1590/S007402761999000200025 . PMid:10224539.

Batista JS, Riet-Correa F, Teixeira MMG, Madruga CR, Simóes SDV, Maia TF. Trypanosomiasis by Trypanosoma vivax in cattle in the Brazilian semiarid: Description of an outbreak and lesions in the nervous system. Vet Parasitol 2007; 143(2): 174-181. http://dx.doi.org/10.1016/j. vetpar.2006.08.017. PMid:16965857.

Boulangé A, Pillay D, Chevtzoff C, Biteau N, Comé de Graça V, Rempeters $\mathrm{L}$, et al. Development of a rapid antibody test for point-of-care diagnosis of animal African trypanosomosis. Vet Parasitol 2017; 233: 32-38. http:// dx.doi.org/10.1016/j.vetpar.2016.11.017. PMid:28043385.

Brener Z. Contribuição ao estudo da terapêutica experimental da doença de Chagas [tese]. Belo Horizonte: Universidade Federal de Minas Gerais; 1961.

Cadioli FA, Barnabé PA, Machado RZ, Teixeira MCA, André MR, Sampaio $\mathrm{PH}$, et al. First report of Trypanosoma vivax outbreak in dairy cattle in São Paulo state, Brazil. Rev Bras Parasitol Vet 2012; 21(2): 118-124. http:// dx.doi.org/10.1590/S1984-29612012000200009. PMid:22832751.

Cadioli FA, Fidelis OL Jr, Sampaio PH, Santos GN, André MR, Castilho KJGA, et al. Detection of Trypanosoma vivax using PCR and LAMP during aparasitemic periods. Vet Parasitol 2015; 214(1-2): 174-177. http:// dx.doi.org/10.1016/j.vetpar.2015.09.001. PMid:26414906.

Cortez AP, Rodrigues AC, Garcia HA, Neves L, Batista JS, Bengaly Z, et al. Cathepsin L-like genes of Trypanosoma vivax from Africa and South America - characterization, relationships and diagnostic implications. Mol Cell Probes 2009; 23(1): 44-51. http://dx.doi.org/10.1016/j. mcp.2008.11.003. PMid:19063960.

Dávila AMR, Silva RAMS. Animal trypanosomiasis in South America. Current status, partnership, and information technology. Ann NY Acad Sci 2000; 916(1): 199-212. http://dx.doi.org/10.1111/j.1749-6632.2000. tb05291.x. PMid:11193622.

Desquesnes M. Livestock trypanosomoses and their vectors in Latin America. Paris: OIE \& CIRAD; 2004.

Fidelis OL Jr, Sampaio PH, Machado RZ, André MR, Marques LC, Cadioli FA. Evaluation of clinical signs, parasitemia, hematologic and biochemical changes in cattle experimentally infected with Trypanosoma vivax. Rev Bras Parasitol Vet 2016; 25(1): 69-81. http://dx.doi.org/10.1590/ S1984-29612016013. PMid:27007249. 
Fikru R, Matetovici I, Rogé S, Merga B, Goddeeris BM, Büscher P, et al. Ribosomal DNA analysis of tsetse and non-tsetse transmitted Ethiopian Trypanosoma vivax strains in view of improved molecular diagnosis. Vet Parasitol2016; 220: 15-22. http://dx.doi.org/10.1016/j.vetpar.2016.02.013. PMid:26995716.

Garcia HA, Rodrigues AC, Rodrigues CMF, Bengaly Z, Minervino AHH, Riet-Correa F, et al. Microsatellite analysis supports clonal propagation and reduced divergence of Trypanosoma vivax from asymptomatic to fatally infected livestock in South America compared to West Africa. Parasit Vectors 2014; 7(1): 210. http://dx.doi.org/10.1186/1756-33057-210. PMid:24885708.

Giordani F, Morrison LJ, Rowan TG, Koning HP, Barrett MP. The animal trypanosomiases and their chemotherapy: a review. Parasitology 2016; 143(14): 1862-1889. http://dx.doi.org/10.1017/S0031182016001268. PMid:27719692.

González LE, García JA, Núñez C, Perrone TM, González-Baradat B, Gonzatti MI, et al. Trypanosoma vivax: a novel method for purification from experimentally infected sheep blood. Exp Parasitol 2005; 111(2): 126129. http://dx.doi.org/10.1016/j.exppara.2005.05.008. PMid:16023641.

Igbokwe IO, Umar IA, Omage JJ, Ibrahim ND, Kadima KB, Obagaiye $\mathrm{OK}$, et al. Effect of acute Trypanosoma vivax infection on cattle erythrocyte glutathione and susceptibility to in vitro peroxidation. Vet Parasitol 1996; 63(3-4): 215-224. http://dx.doi.org/10.1016/0304-4017(95)00887-X. PMid:8966988.

Kato CD, Matovu E, Mugasa CM, Nanteza A, Alibu VP. The role of cytokines in the pathogenesis and staging of Trypanosoma brucei rhodesiense sleeping sickness. Allergy Asthma Clin Immunol 2016; 12(1): 4. http:// dx.doi.org/10.1186/s13223-016-0113-5. PMid:26807135.

Landis JR, Koch GG. The measurement of observer agreement for categorical data. Biometrics 1977; 33(1): 159-174. http://dx.doi. org/10.2307/2529310. PMid:843571.

Madruga CR, Araújo FR, Cavalcante-Goes G, Martins C, Pfeifer IB, Ribeiro LR, et al. The development of an enzyme-linked immunosorbent assay for Trypanosoma vivax antibodies and its use in epidemiological surveys. Mem Inst Oswaldo Cruz 2006; 101(7): 801-807. http://dx.doi. org/10.1590/S0074-02762006000700016. PMid:17160291.

Mattioli RC, Faye JA, Jaitner J. Estimation of trypanosomal status by the buffy coat technique and an antibody ELISA for assessment of the impact of trypanosomosis on health and productivity of N'Dama cattle in the Gambia. Vet Parasitol 2001; 95(1): 25-35. http://dx.doi.org/10.1016/ S0304-4017(00)00411-8. PMid:11163695.

Mattioli RC, Wilson RT. Trypanosomes, tsetse and trypanotolerance: coevolution in Tropical Africa. Parassitologia 1996; 38(3): 531-535. PMid:9257342.

Osório ALA, Madruga CR, Desquesnes M, Soares CO, Ribeiro LRR, Costa SCG. Trypanosoma (Duttonella) vivax: its biology, epidemiology, pathogenesis, and introduction in the New World - A Review. Mem Inst Oswaldo Cruz 2008; 103(1): 1-13. http://dx.doi.org/10.1590/S007402762008000100001 . PMid:18368231.

Rodrigues CMF, Olinda RG, Silva TMF, Vale RG, Silva AE, Lima GL, et al. Follicular degeneration in the ovaries of goats experimentally infected with Trypanosoma vivax from the Brazilian semi-arid region. Vet Parasitol 2013; 191(1-2): 146-153. http://dx.doi.org/10.1016/j. vetpar.2012.08.001. PMid:22921989.

Schenk MAM, Mendonça CL, Madruga CR, Kohayagawa A, Araújo FR. Avaliação clínico-laboratorial de bovinos nelore infectados experimentalmente com Trypanossoma vivax. Pesq Vet Bras 2001; 21(4): 157-163. http:// dx.doi.org/10.1590/S0100-736X2001000400006.

Silbermayr K, Li F, Soudré A, Müller S, Sölkner J. A novel qPCR assay for the detection of African animal trypanosomosis in trypanotolerant and trypanosusceptible cattle breeds. PLoS Negl Trop Dis 2013; 7(8): e2345. http://dx.doi.org/10.1371/journal.pntd.0002345. PMid:23967357.

Tran T, Napier G, Rowan T, Cordel C, Labuschagne M, Delespaux $\mathrm{V}$, et al. Development and evaluation of an ITS1 "Touchdown" PCR for assessment of drug efficacy against animal African trypanosomosis. Vet Parasitol 2014; 202(3-4): 164-170. http://dx.doi.org/10.1016/j. vetpar.2014.03.005. PMid:24685024.

Woo PTK. The haematocrit centrifuge technique for the diagnosis of African Trypanosomiasis. Acta Trop 1970; 27(4): 384-386. PMid: 4396363. 